\title{
Formation and implementation of urban policy using the example of Saransk, Russia
}

\author{
Elvira Egereva ${ }^{1, *}$, Alina Barmenkova ${ }^{2}$, Alexei Barmenkov ${ }^{2}$, and Dmitry Surovtsev ${ }^{1}$ \\ ${ }^{1}$ National Research Moscow State University of Civil Engineering, 129337, 26 \\ Yaroslavskoye Shosse, Moscow, Russia \\ ${ }^{2}$ National Research Mordovia State University, 430005, 68 Bolshevistskaya str., Saransk, \\ Republic of Mordovia
}

\begin{abstract}
In the process of research the essence of urban policy was disclosed, the basic concept of urban space development were considered, historical prerequisites for the formation of public spaces and modern world trends were identified, a review of the regulatory framework for the formation and implementation of urban planning policies was carried out, priority directions for improving the efficiency of the mechanisms for implementing the urban development policy of the district of Saransk in conditions of the transformation of public spaces were developed.
\end{abstract}

\section{Introduction}

Nowadays business, social and at the same time construction activity were increased strongly enough. In connection with this it's necessary to improve infrastructure, construction, reconstruction and also ensuring good ecological condition of cities. All this affects town-planning activity and considerably raises its role and importance.

The main task of town-planners in good linkage between planning and transport of urban structures [1]. Availability and quality of transport service affects investment and social attractiveness of an object. Also, the concentration of the population in a particular urban area directly depends on the location of the main urban highways. When planning the organization of urban transport systems, it is necessary to take into account their high cost, which causes high inertia and, over time, most often there is a significant lagging behind the pace of development of the city. All these tasks determine the relevance of the research topic.

Theoretical and methodological bases of formation and implementation of urban policy are rather fully were investigated in the article Robin E., Auto M. [2]. The research relies on works of the famous scientists, who work at the interface of town planning and architecture and also experts, who consider economical and town-planning problems, features of the organization of the urbanistic habitat and its perceptions.

\footnotetext{
${ }^{*}$ Corresponding author: egerevaen@mail.ru
} 


\section{Materials and Methods}

The purpose of work is development of the priority directions of increase in efficiency of mechanisms implementation of urban policy of the district Saransk in the conditions of need of transformation of public spaces.

This purpose predetermined need of the solution of the following tasks:

- to study historical prerequisites of formation of public spaces, modern world trends and features of town-planning transformations;

- to study standard and legal bases of formation and implementation of urban policy in municipal units;

- to define a city town planning role in formation of the urban environment;

- to reveal new conditions of town planning in Russia and to study their potential impact on formation of the scientific concept of town planning;

- to analyses the current state of town planning and to mark the main problems of its reforming in Saransk;

- to assess the level of satisfaction with architectural and planning structure and organization of public space;

- to develop the main directions of increase in efficiency of mechanisms of implementation of urban policy Saransk in the conditions of need of transformation of public spaces.

Object of a research is the urban district Saransk.

The subject of research is the mechanism of formation and implementation of urban planning policy in urban district Saransk.

Research methods: the research is based on application of system approach with use of methods of the comparative, logical, settlement and design analysis, scientific analogies, empirical generalization, also economical and statistical and sociological methods.

Scientific works of domestic and foreign authors on the studied subject formed the publication for carrying out a research information base, in periodicals, normative legal acts of the Russian Federation and the Republic of Mordovia, analytical and departmental information of local governments of the city district Saransk.

\section{Results}

\subsection{Theoretical bases of formation and implementation of urban policy. Historical prerequisites of formation of public spaces and modern world trends. Regulatory framework}

Life activity of most of modern people is made in the conditions of the urban environment. In modern Russia the share of urban population reaches more than $70 \%$, therefore, most of people of our country live in the big and small cities today. The city - integral of human activity, the center of various types of the functions which are carried out which define "face" of the city [3].

The modern citizen perceives all territory of the city as the public space and expects from it safety, comfort, functionality and an esthetics. Rationally built urban environment allows to lower degree of social tension, supports a solution of social demographic problems.

In comfortable, modern and safe areas of the cities creative and intellectual clusters form, new points of an attraction of talented people are created, the demand of the real estate grows, new jobs are created due to increase in demand for household services. 
Modern interpretations of space development of the city - result of long evolution of views of representatives of the different scientific directions (economists, sociologists, geographers, engineers-town-planners, managers) forming for the 18-21st centuries [4]. Their systematization allowed to reveal differences in ideas of the territorial device, the nature and the main subjects of space development of the cities.

The most important theoretical provisions (in terms of a research of the nature and an entity of problems of space development of the city) in the following:

- the city is the holistic organism representing unity of material and social space of life activity of city community which structural heterogeneity is shown in the form of differentiation of intracity territories [5];

- spatial development is a cyclical process caused by the contradictory effects of transformations in the sociocultural or material environment, the subjects of which are the population, property owners (including land owners), developers, local authorities united by the interests of living together and running a business within local urban areas.

The principles of spatial development are a kind of "load-carrying structure" uniting activity of all subjects of city planning in a uniform consistent complex.

Achievement of balance of the material and social environment of the local urban areas (LUA) requires a deep study of specifics of relations developing between investors, builders, land owners, the population and local governments, and the choice of methods adequate to market conditions and instruments of regulation of relationship of the main subjects of LGT [6].

Methods of administrative regulation were built according to the adopted concept of spatial development: town planning (the centralized economy) - a town regulation (market economy) - urban development (socially oriented economy) [7,8]. The directiveadministrative, business-oriented and social-oriented approaches correspond to them, the fundamental differences between which are presented in Table 1.

Evolution of public territories (urban centers) demonstrates that public space, first of all, the place in the city, the street or the square where there is a public life of its population.

A variety of types of activity which are implemented in the territory of the public centers, predetermines the need for creation of the various spaces, witch correspond to the functions which are carried out by them. In the composition of public centers are formed spaces of different sizes, functional purposes, focused on different composition of users.

Town-planning search of the concept of the city of the future. Many projects of the cities of the future were developed in the 70-80th years. Some leading ideas in design of the cities of the future [9]:

1) To lift future city up, using the framework of their metal structures leaning on the earth, but leaving a maximum of the territory for green plantings, agriculture, rest.

2) Other important idea of projects of the cities of the future - their mobility, desire to provide for the dynamic development of the city. The group of the English architects "Arkigrem" creates projects among which the system "Plugin City" stands out [10]. The replaced inhabited cells, physical and which obsolescence can make from 3 to 15 years are inserted into the nests which are located on the bearing structures, which updated once approximately in 40 years and contain the main communications.

Today comes the understanding that it is necessary to radically revise approaches to planning the urban environment. In a generalized form, the observed change of paradigms in the development of cities is as follows [11]:

- there is a change of basic concepts: to replace images "the city as office", "city is a car" (linear and fragmentary thinking, rigid rationalism) come the models "the city for life","city promoting a healthy lifestyle" (the cross-disciplinary, innovative thinking, first of all, population psychology, etc.) [12]; 
- the combination of approaches "the city as the project" and "the city as a mosaic of projects" acquires relevance.

Table 1. Ratio of the main characteristics of various approaches to the spatial analysis, planning and regulation.

\begin{tabular}{|c|c|c|c|}
\hline \multirow{2}{*}{$\begin{array}{c}\text { The main } \\
\text { Characteristics of } \\
\text { approaches }\end{array}$} & \multicolumn{3}{|c|}{ Approaches to the spatial analysis, planning and regulation } \\
\hline & $\begin{array}{c}\text { Directive } \\
\text { administrative }\end{array}$ & Business oriented & $\begin{array}{c}\text { Social } \\
\text { oriented }\end{array}$ \\
\hline Conceptual basis & Town planning & Town regulation & Town regulation \\
\hline $\begin{array}{l}\text { Subjects of the } \\
\text { analysis, planning } \\
\text { and regulation of } \\
\text { development }\end{array}$ & $\begin{array}{l}\text { Institutes of state } \\
\text { planning; } \\
\text { departmental } \\
\text { authorities of } \\
\text { planning } \\
\end{array}$ & $\begin{array}{c}\text { Territorial (regional } \\
\text { and local) authorities } \\
\text { and business structures }\end{array}$ & $\begin{array}{l}\text { Territorial authorities, } \\
\text { representatives of } \\
\text { business, } \\
\text { representatives of the } \\
\text { population }\end{array}$ \\
\hline $\begin{array}{l}\text { Nature of interaction } \\
\text { of subjects of } \\
\text { economic activity }\end{array}$ & $\begin{array}{c}\text { Directive strictly } \\
\text { Regulated nature of } \\
\text { interaction. Economic } \\
\text { subjects are not } \\
\text { independent. Making } \\
\text { decisions as a result of } \\
\text { many approvals }\end{array}$ & $\begin{array}{c}\text { Interaction of } \\
\text { independent economic } \\
\text { subjects which are } \\
\text { regulated by precepts } \\
\text { of law general for all } \\
\text { participants are strictly } \\
\text { unregulated }\end{array}$ & $\begin{array}{l}\text { Public and private } \\
\text { partnership. } \\
\text { Interaction of the } \\
\text { power, business, the } \\
\text { population } \\
\text { concerning } \\
\text { improvement of LGT } \\
\text { - social development } \\
\text { of LGT } \\
\end{array}$ \\
\hline $\begin{array}{c}\text { Contents of the } \\
\text { analysis of spatial } \\
\text { organizations of } \\
\text { cities }\end{array}$ & $\begin{array}{l}\text { Government spending } \\
\text { standards; the value of } \\
\text { final consumption; the } \\
\text { level of costs of the } \\
\text { sphere of circulation; } \\
\text { optimal placement of } \\
\text { productive forces }\end{array}$ & $\begin{array}{l}\text { Investment indicators } \\
\text { of private construction } \\
\text { projects; efficiency of } \\
\text { use of local resources, } \\
\text { the most effective } \\
\text { option of use } \\
\text { (NEI)land plots; } \\
\text { quantitative indices of } \\
\text { economic growth }\end{array}$ & $\begin{array}{c}\text { Qualitative } \\
\text { characteristics of } \\
\text { social-economic } \\
\text { development of LGT; } \\
\text { characteristics of } \\
\text { needs, features of } \\
\text { behavior and degree } \\
\text { of satisfaction of } \\
\text { inhabitants of LGT }\end{array}$ \\
\hline $\begin{array}{l}\text { Main methods of } \\
\text { regulation }\end{array}$ & $\begin{array}{l}\text { Branch, territorial } \\
\text { (regional, city) } \\
\text { development plans. } \\
\text { General plans of } \\
\text { settlements/ }\end{array}$ & $\begin{array}{c}\text { Documents of } \\
\text { territorial planning. } \\
\text { Rules of land use and } \\
\text { building (PZZ). } \\
\text { Documents of planning } \\
\text { of territories }\end{array}$ & $\begin{array}{l}\text { Development of } \\
\text { methods witch is } \\
\text { based on equal } \\
\text { participation in } \\
\text { making } \\
\text { decisions of the } \\
\text { government, business } \\
\text { and population is } \\
\text { required }\end{array}$ \\
\hline
\end{tabular}

Table 2. Types of the open public spaces corresponding to objects of different functional purpose as a part of the public centers.

\begin{tabular}{|c|c|}
\hline The name of objects in public centers & Types of the formed open spaces \\
\hline Administrative buildings, institutions & Area, avanarea, kurdoner \\
\hline Cultural and spectacular objects & $\begin{array}{c}\text { The square, the square in front with adjacent } \\
\text { landscape and recreational territories }\end{array}$ \\
\hline Trading and public trading facilities & $\begin{array}{c}\text { Area, the pedestrian street with adjacent } \\
\text { landscape and recreational territories }\end{array}$ \\
\hline $\begin{array}{c}\text { Tourist objects and complexes, memorial and } \\
\text { historical objects }\end{array}$ & Square, street, park, square, boulevard, seafront \\
\hline Places of public events (festivals, holidays etc.) & $\begin{array}{c}\text { The area, the system of the areas with } \\
\text { landscape and recreational territories }\end{array}$ \\
\hline Places of short-term rest & Park, small garden \\
\hline
\end{tabular}


From town-planners don't ask any more to create "new places". All know English world "expensive" it is the connection of buildings and spaces with the atmosphere that they create for a person. When developing objects the balance between authenticity and a context is important, and "the franchize architecture" with sample projects does not approach here.

The modern period of the economic development of the Russian Federation is characterized by the presence of tendencies to reform the situation that has taken shape since the beginning of the 1990s. systems of norms of law in the field of urban planning. The Civil, Town Planning and Land Codes, the Federal Law "On Architectural Activity in the Russian Federation" and many other regulatory legal acts have been adopted.

The branch of town planning law includes the Constitution of the Russian Federation, the Town Planning Code of the Russian Federation and other regulatory legal acts of the Russian Federation, as well as laws and other regulatory legal acts of the constituent entities of the Russian Federation. Thus, the system of laws in the field of construction management is three-tier and consists of the Constitution of the Russian Federation, federal laws and laws of the constituent entities of the Russian Federation. The leading role in this system is played by the Constitution of the Russian Federation and federal laws (first of all the GRK Russian Federation).

The main strategic objectives are to ensure the safety of territories, capital construction projects and the creation of the most favorable conditions for human life. In this regard, we can distinguish three directions of urban planning policy (Figure 1)

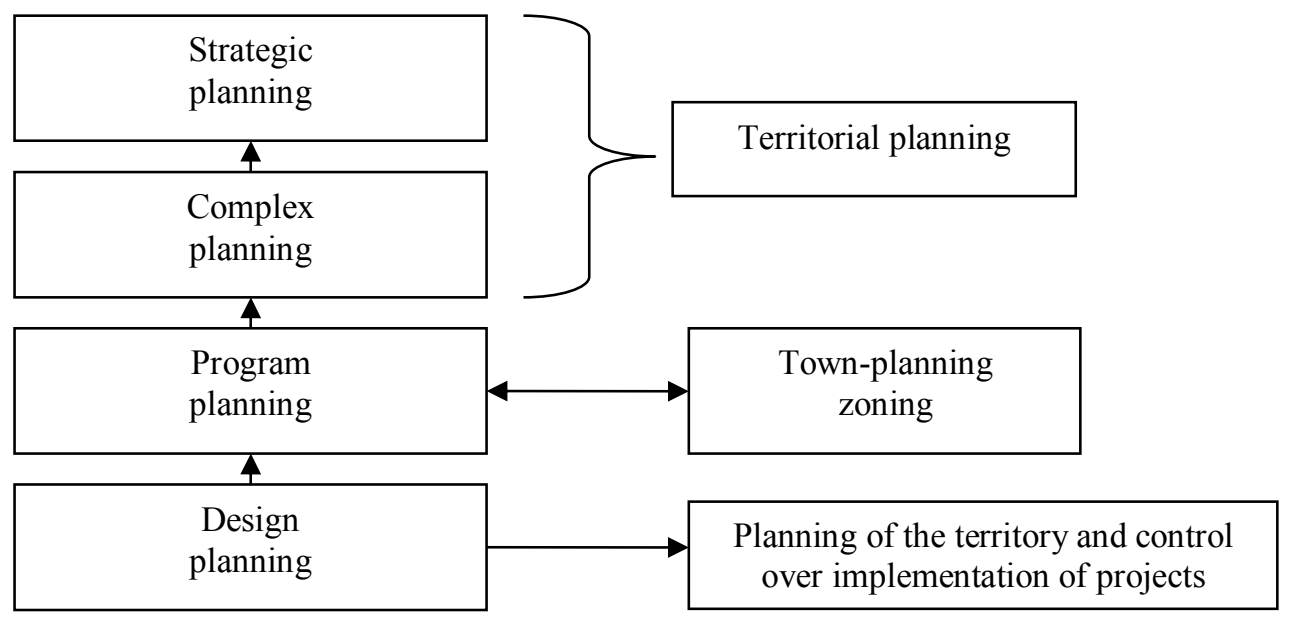

Planning stages SIR of the

municipal unit

Stages of territorial planning (town-

Fig. 1. Scheme of urban policy of the municipal unit.

Thus, the development of the economy in a rapidly changing world predetermines the need for continuous improvement of urban planning policy, which, in fact, is observed in Russia. 


\subsection{The analysis and assessment of efficiency of mechanisms of formation and implementation of urban policy to Saransk. Research of mechanisms of formation and implementation of urban policy. Assessment of level of satisfaction with architectural and planning structure and organization of public space}

Now the main functions Saransk are:

a) Function of the industrial center. First of all the city represents the industrial center in which the largest enterprises of the region are concentrated. The main productions of the urban district Saransk are:

- production and power distribution, warm, gas and water;

- electrotechnical industry;

- agro-industrial complex;

- pharmaceutical industry;

- rubber industry.

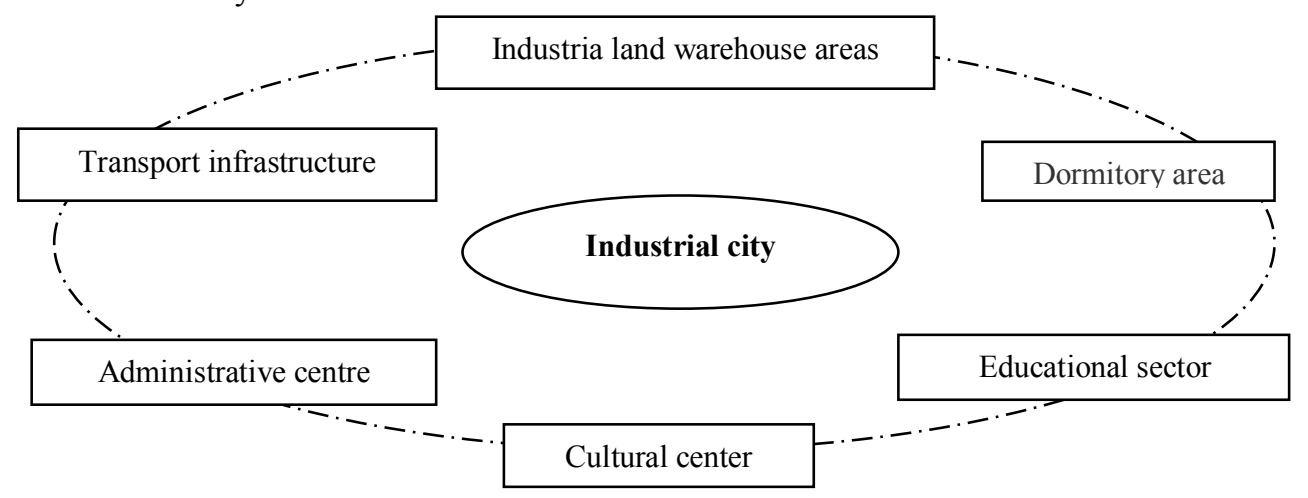

a) Traditional structure of the city

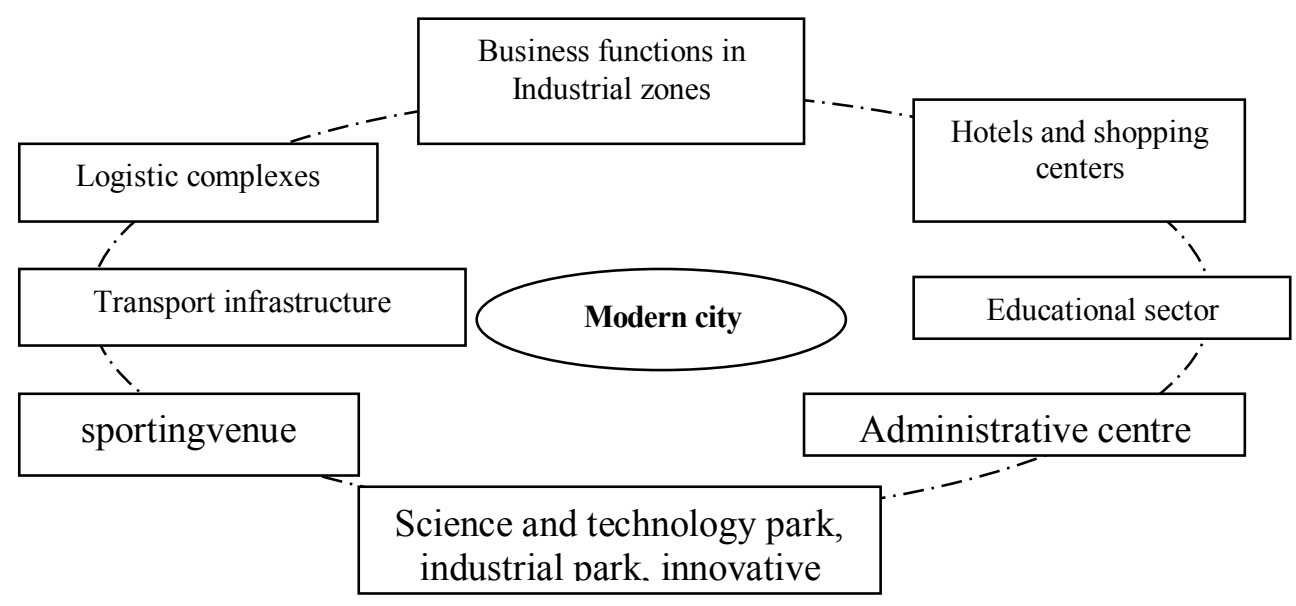

Fig. 2. Structure of the city.

b) Modern structure of the city

b) Function of the administrative center. Despite deep integration of functions of the industrial center and center of the territorial subject of the federation, market changes demand intensive formation of the new town-planning functions allowing to provide 
capitalization of intellectual potential and contributing to the development of competitive advantages of the territory [13].

The formed functions of city space:

c) Function of the sports center of macroregional and federal level. Huge attention is traditionally paid to development of mass physical culture, for children and young people and professional sport in the Republic of Mordovia. An indicator of development of the sports industry is holding large sporting events of the All-Russian and international levels. Saransk hosted IAAF World Cup Grand Prix Finals on sports walking, the short track, figure skating, sports walking Championships of Russia track and field for athletics, the 2018 FIFA World Cup twice.

d) Function of the center of the formed Saransk agglomeration. Now the trend of formation of the Saransk agglomeration which part can be Ruzaevka, a part of Lyambirsky district, a part of Romodanovsky district, settlement of Chamzinka and urban district Saransk is traced.

e) Function of education center of regional value. Saransk takes the second place among the cities of the Volga Federal District (VFD) with the population less than 1 million people by the number of students of higher education institutions for 1000 of the population. In $2015 / 2016$ academic year the number of students of higher education institutions made 43620 people.

Saransk since 2004 takes prizes in the federal competition "The Most Well-planned City of Russia", thanking both actions for improvement of the city, and reconstruction of separate objects. Improvement of the 1st turn of the embankment of the Saranka River, reconstruction of the park of A.S. Pushkin are so far made, Saint F. Ushakov's Cathedral is constructed (which is the hallmark of the city).

According to the approved program for complex improvement of domestic territories in the city district Saransk for the beginning of 2017350 yards for the sum over 300 million rubles were repaired. These actions allowed to increase number of playgrounds for children preschool and younger school age, and the value of the corresponding indicator was 1.83 sq.m on the person.

Let's consider the mechanism of implementation of urban policy in the city district Saransk (figure 3).

\begin{tabular}{|l|}
\hline Council of deputies of the city district Saransk \\
\hline $\begin{array}{c}\text { The Deputy Head of the city district Saransk - the Headmaster of the department } \\
\text { of perspective development of Administration of the city district Saransk }\end{array}$ \\
\hline $\begin{array}{c}\text { Management of town planning and architecture } \\
\text { Administrations of the city district Saransk }\end{array}$ \\
\hline
\end{tabular}

Fig. 3. Mechanism of urban policy of the city district Saransk.

The mechanism of urban policy is defined by the existing standard and legal documents. It is possible to carry the master plan, rules of land use and building and also local standards of town-planning design to town-planning standard legal instruments of regulation of development of municipal units. The general mechanism of urban policy and its main tools can be presented in figure 4 form. 


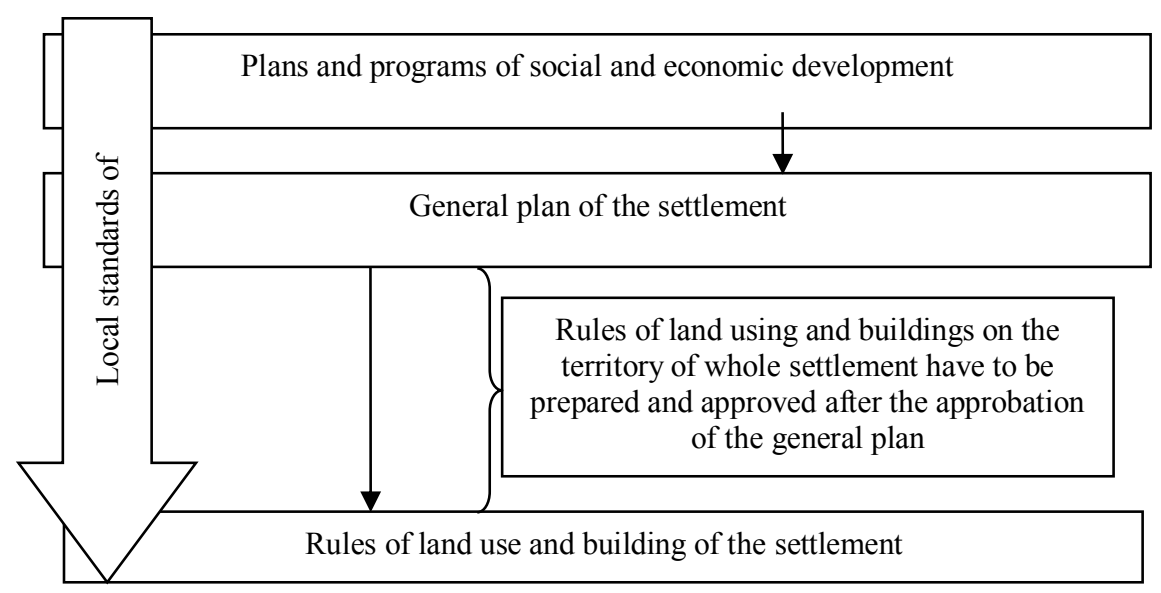

Fig. 4. Scheme of standard regulation of urban policy of the municipal unit.

In figure 5 tools of urban policy of the city district Saransk are presented. The main tool regulating urban policy in the territory of the city district Saransk is the Master plan of the city district Saransk approved by the decision of Council of deputies of the city district Saransk of April 23, 2014 No. 333 "About the approval of the Master plan of the city district Saransk".

Let's carry out the assessment of level of satisfaction with architectural and planning structure and organization of the city.

Research objective: to determine the level of satisfaction of inhabitants of the territory with architectural and planning structure and organization of public space.

Research problems:

- to study features of accommodation in the territory;

- to reveal the main shortcomings and unresolved problems;

- to define features of city infrastructure.

Research hypotheses:

a) Subject to modeling are processes of activity in city space: life, rest, work.

b) The main function - creation of types and forms of the dwelling which correspond to social conditions, and is defined by the subject of modeling depending on a task which he should solve.

c) The accommodation conditions are more comfortable, the satisfaction of inhabitants with the territory is more.

d) Life, rest, work is a basis of satisfaction of inhabitants.

Research method - questionnaire of level of satisfaction with architectural and planning structure and organization of public space.

By results of carried out polls were made the following conclusion:

- the most part of respondents can fully estimate satisfaction of architectural and planning structure and organization of public space of the city.

- most of respondents work as government employees and in education - 17\%, industrial production $-15 \%$ and construction $-14 \%$ follows further.

- concerning satisfaction with accommodation conditions: are completely satisfied $18 \%$ of respondents, are rather satisfied, than unsatisfactorily $-30 \%$, are partially satisfied $-29 \%$, it is rather unsatisfactorily, than are satisfied $-12 \%$, absolutely unsatisfactorily $8 \%$ (on the social status pensioners), found it difficult to answer $-3 \%$ (students, pupils).

- most of respondents consider important for life existence of city transport and the equipped situations, level of the salary and compliance with laws. 
- most of respondents are completely satisfied with access to education, compliance with laws, financial position and political freedoms.

- the dissatisfaction is traced by the equipped places of family leisure, sports constructions in the area, road condition, existence of recreation areas and transport means of communication - all these problems are solved by urban policy of the city district Saransk.

- most of the interviewed inhabitants consider that in the next years in the long term nothing will change $-34 \%$, some consider that there will be little changes $-24 \%$, and $13 \%$ expect change to the best.

In this regard development of the new directions of town-planning activity meeting the requirements of the present and capable to improve quality of life of citizens is obviously necessary.

\begin{tabular}{|c|}
\hline $\begin{array}{l}\text { General plan of the city district Saransk } \\
\text { is approved by the decision of Council of deputies of the city district Saransk } \\
\text { of } 23 \text { April , 2014 No. } 333 \\
\text { "About the approval of the Master plan of the city district Saransk" }\end{array}$ \\
\hline 7 \\
\hline $\begin{array}{l}\text { Rules of land using and building } \\
\text { are approved by the decision of Council of deputies of the city district Saransk } \\
\text { of } 6 \text { May , 2016 No. } 516 \\
\text { "About the approval of Rules of land use and building of the city district Saransk" }\end{array}$ \\
\hline 7 \\
\hline $\begin{array}{l}\text { Documents of planning of the territory: } \\
\text { - projects of plannings territories as separate documents; } \\
\text { - projects of plannings territories with projects of land surveying of territories in } \\
\text { their structure; } \\
\text { - projects of land surveying of territories as separate documents; } \\
\text { - town-planning plans of land plots. }\end{array}$ \\
\hline
\end{tabular}

Fig. 5. Tools of urban policy of the city district Saransk.

\subsection{The main directions of increase in efficiency of mechanisms of implementation of urban policy Saransk in the conditions of need of transformation of public spaces}

Modern development of the territory is based on its natural and technological resources (communication opportunities). For this reason, against the background of reduction of total number of the population of municipal units the trend of reduction of population of remote settlements and almost total disappearance of the villages and settlements which are not provided with transport connection and engineering infrastructure is clearly visible [14].

The main criteria of transport availability of the territory are the cost of transport services, time of a way, comfort of achievement of the goal of a route (work - the house socially important institutions).

For the solution of territorial problems, it is necessary to set a vector of investment development of the territory, first; secondly, town-planning documentation has to define territorial borders and standard economic limits of this development on the basis of assessment of criteria of recovery from the crisis, gradual stabilization of economy, an investment of budgetary funds in engineering and transport infrastructure and also in development of socially important objects. 
Let's allocate the priority directions of complex development of inhabited territories Saransk:

1. Formation of qualitatively new system of city design. For improvement of visual view of the city it is necessary to create the system of city design which will include not only unique city objects (the embankment, the square, etc.), but also objects of trade and public catering, the system of gardening of the city, the city lighting system etc.

To Saransk (and the Republic of Mordovia) a large number of the lighting enterprises is concentrated. The city can make the system of street lighting one of elements of the unique style.

2. Redevelopment of "sleeping" areas has to be directed to formation of the urban environment, comfortable for accommodation, where the main function of space accommodation of the population. Redevelopment has to include $[15,16]$ :

shopping centers and shopping malls. They will become the new subcenters of city space of dormitory areas, having replaced with themselves the markets that change of structure of consumption of services will bring with itself. The main objective is a providing the population with modern formats of consumption what it is necessary for:

- development of modern formats of trade not only in the center, but also in districts of the city: redevelopment of the existing trade spaces, reservation of prospective sites under trade and entertaining objects, etc.

- attraction for implementation of large projects of skilled investors which can be both trade retailers, and the professional developers capable is competent to position the projects. Besides, often $20-25 \%$ of the area of modern shopping center are occupied by anchor tenants as whom retail chain stores or large shop of electronics act;

- the ensuring transport availability of new trade zones including start of the new routes of public transport focused on operating time of new objects of the urban environment.

3. Formation in dormitory areas of modern public spaces includes ensuring high level of improvement of zones around shopping centers, placement in a zone of pedestrian availability of cultural institutions, sport, public catering for providing their inhabitants with those services which inhabitants of the downtown use. Forecasting of change of a way of life of the population and creation of the flexible architectural environment which could adapt to it easily becomes one of important points.

4. Creation and development of new recreation areas:

- creation of water park on the Insar River which has to be created in a complex with other types of service: hotel, trade and entertaining;

- creation of a modern recreational zone in Proletarsky district the cities when creation of the environment for carrying out free time by all age groups of the population, providing with the corresponding infrastructure (various services and entertainments), design of the theme park or the park focused on family holiday becomes an important condition.

The problem of complex land development solves a problem of social security of the population of Saransk which has to pass within reforming of the sphere of construction (capital construction and repair), investment activities (in the form of participation in fixed capital), design and surveying activity, standardization, connection to communications, assessment of cadastral cost of real estate objects and, respectively, the sizes counted on its basis. The serious problem interfering the solution of a problem of complex development of territories is the lack of the regulating mechanism of construction of utilities, allocations of costs on laying of networks and their subsequent operation, or as all-house property, or property of the city district. 


\section{Conclusion}

Today the cities are considered as the place for life as the place where it is possible to create comfortable and friendly to the person an environment more often. There are two reasons for this. First, this approach of a post-industrial era, at least, in the developed world. Secondly, it is globalization. The most essential consequence of globalization - nobody and nothing can hide behind national borders from the global competition today. The condition of the cities cannot be considered any more only as an internal problem of this or that country - the cities participate in the global competition, and it is the competition for people, for the most qualified and creative shots.

At the same time, the cities become the main instrument of sustainable development of a human civilization. Development of the modern cities creates a number of the most serious calls; however the cities become the most effective answer to these calls. The city forms the main demand for innovative solutions, however innovations are created in cities. The city is the main culprit of environmental degradation and climate change on the earth, however the city can become the most effective solution of this really global problem. The list can be continued.

It is also important that management of the cities relate to the sphere of exclusive competence of public institutes, first of all - state and municipal authority. Development of the cities is carried out generally by money of taxpayers and, respectively, is rather rigidly regulated by the authority. Therefore city development is one of the most effective tools, witch allow to the state to influence to the solution of a number of problems of modernization of the country in general.

Thus, the process of transformation of the cities which began around the world is not only a serious call, but also unique chance to accelerate modernization of economy and society in our country, to turn Russia into the attractive place for life.

\section{Reference}

1. A. Adu-Gyamfi, Land Use Policy 92, 104440 (2020). DOI: 10.1016/j.landusepol.2019.104440.

2. E. Robin, M. Acuto, Political Geography 66, 76-87 (2018). DOI: 10.1016/j.polgeo.2018.08.013.

3. S. A. Matovnikov, N. G. Matovnikova, Procedia Engineering 150, 1966-1971 (2016). DOI: 10.1016/j.proeng.2016.07.199.

4. I. Yamshanov, V. Goryunov, V. Murgul, Procedia Engineering 117, 663-674 (2015). DOI: 10.1016/j.proeng.2015.08.229.

5. M. G. Sandoval, J. A. Díaz, R. Z. Ríos-Mercado, Expert Systems with Applications 146, 113150 (2020). DOI: 10.1016/j.eswa.2019.113150.

6. S. Ershova, E. Smirnov, Transportation Research Procedia 20, 180-184 (2017). DOI: 10.1016/j.trpro.2017.01.047.

7. Dr. A. Mersal, Procedia Environmental Sciences 34, 49-61 (2016). DOI: 10.1016/j.proenv.2016.04.005.

8. I. Tikoudis, E. T. Verhoef, J. N. Ommeren, Transportation Research Part B: Methodological 117, 342-359 (2018). DOI: 10.1016/j.trb.2018.08.014.

9. S. Griffiths, B. K. Sovacool, Energy Research \& Social Science 62, 101368 (2020). DOI: 10.1016/j.erss.2019.101368. 
10. D. Dreier, S. Silveira, D. Khatiwada, K. V. Fonseca, R. Nieweglowski, R. Schepanski, Transportation Research Part D: Transport and Environment 58, 122-138 (2018). DOI: 10.1016/j.trd.2017.10.015.

11. J. Wohlfahrt, F. Ferchaud, B. Gabrielle, C. Godard, B. Kurek, C. Loyce, O. Therond, Journal of Cleaner Production 232, 898-909 (2019). DOI: 10.1016/j.jclepro.2019.05.385.

12. J. Guimarães, E. Severo, L. Felix, W. Preston Leite Batista Da Costa, F.T. Salmoria, Journal of Cleaner Production 253, 119926 (2020). DOI: 10.1016/j.jclepro.2019.119926.

13. B. S. Bezerra, A. L. Lordelodos Santos, D. V. G. Delmonico, Transportation Research Part A: Policy and Practice 132, 808-822 (2020). DOI: 10.1016/j.tra.2019.12.006.

14. H. Zeng, X. Yu, J. Zhang, Cities, 94, 70-79 (2019). DOI: 10.1016/j.cities.2019.05.029.

15. M. Egerer, C. Ordóñez, B. B. Lin, D. Kendal, Urban Forestry \& Urban Greening 46, 126445, (2019). DOI: 10.1016/j.ufug.2019.126445.

16. L. V. Pushkareva, O. A. Galochkina, O. L. Bezgacheva, Espacios 40(4), 22 (2019) 